\title{
Chapter 20 \\ Skills for Inclusive and Sustainable Growth in Developing Asia and the Pacific
}

\author{
Shanti Jagannathan
}

The growing prominence of Asian economies and corporations, against the backdrop of globalization and technological progress, is leading to long-term changes in trade, business, and labor markets. Asia's economies have achieved remarkable growth rates. According to the ADB study Asia 2050: Realizing the Asian Century, if Asia continues to grow on its recent trajectory, it could account for $51 \%$ of world GDP by 2050 (compared with 27\% in 2010) (ADB 2011).

Strengthening education and skills is an important policy lever for development. To quote, Ho Chi Minh said: To reap a return in 10 years, plant trees. To reap a return in 100, cultivate the people. Support to education is a key priority in enabling developing countries to become knowledge-based economies. Education and skills development are crucial to achieving inclusive growth and sustainable green growth. Governments are considering policy options to strengthen the human resource base required to serve the growth sectors of the economy, to avoid the "middle income trap," and to increase employment.

Jobs and skills are pressing challenges for developing countries. Paradoxically, there is also a growing concern of skills mismatch. How do skills training systems support skills acquisition and continued upgrading? How does the education system interface and interact with labor markets and industries to coordinate skills development with changing industry needs? What are good practices and lessons from different countries and regions that can better inform skills development policy making? In Manila, 12-13 December 2011, the event brought together diverse top-level professionals in government, the private sector, and academia. A range of issues on strengthening skills development systems and technical and vocational education and training (TVET) were discussed at the forum, particularly in the

\footnotetext{
S. Jagannathan $(\bowtie)$

Regional and Sustainable Development Department, Asian Development Bank, ADB Avenue, 1550 Mandaluyong, Manila, Philippines

e-mail: sjagannathan@adb.org 
context of advancing inclusive growth and increasing employment. This brief has been prepared by drawing on papers presented and key messages discussed at the forum (http://www.adb.org/news/events/skills-inclusiveand-sustainable-growthdeveloping-asia-pacific).

\section{Skills for Growth and Competitiveness}

\section{Jobs and Skills Are Pressing Development Challenges}

Global unemployment stood at 200 million in 2011, almost half of that in Asia and the Pacific. In the People's Republic of China (PRC), 25 million people need to be employed in urban areas annually, while current annual job vacancies are only 12 million. India has a target of creating a pool of skilled workers of 500 million by 2022. Skills training systems are pressed to create "work-ready" people to increase employment. It is acknowledged that growth alone is not enough. More jobs and greater inclusiveness help to redress poverty, inequality, and exclusion.

However, skills development and TVET are only part of the strategy for employment, particularly for youth and vulnerable groups. Table 20.1 shows that the global youth unemployment rate in 2011 was $12.7 \%$, compared with $4.6 \%$ for adults. An estimated 6.4 million young people dropped out of the world labor market in 2011. Countries with a youthful demographic profile need to consider strategies that would improve job prospects for young adults. Of India's current population, $47.8 \%$ is below 29 years, which will further increase to $49.9 \%$ in 2021 . The mean age in Indonesia is less than 29.

A large share of employment in developing Asia is found in the informal sector. Improved skills increase prospects of better-quality jobs. Specialized strategies for skills training for small and medium enterprises would help their growth and increase employment prospects for workers in the informal sector. Skills training policies need to be augmented with labor market and social protection policies to redress the obstacles to workforce participation, increase employment, and reduce vulnerability of employment.

\section{Addressing Skills Mismatch Calls for Not Just Upskilling but Also "Right Skilling"}

Emerging and modernizing economies are very much concerned with upskilling their workforce to meet the demands of knowledge-intensive and high-technology industries. Asian technology has reached or is close to the global cutting edge in many areas such as electronics, computers, information technology, services, communications, pharmaceuticals, and biotechnology. Technology adoption in 


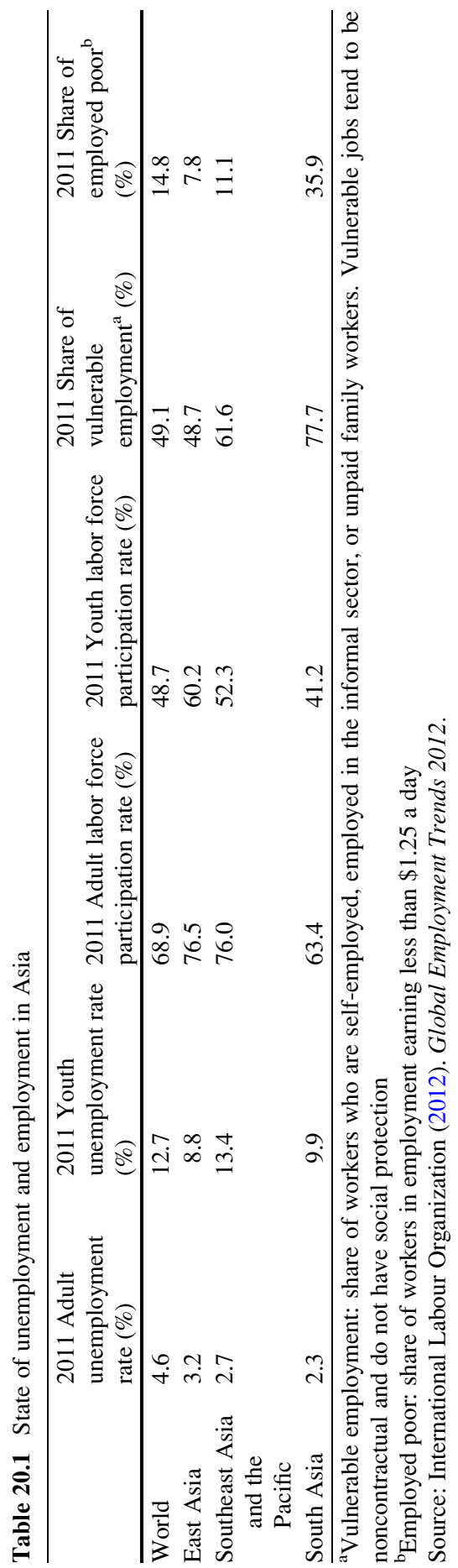


Asian countries has proceeded at a rapid pace, exerting pressure on the level of skills required in the workforce.

In the PRC, technological progress and industrial restructuring and upgrading are leading to a shortage of skilled workers. The PRC's National Medium- and Long-term Talent Development Plan (2010-2020) addresses vocational training and employment promotion. In the Philippines, a priority is to increase the number of qualified technicians at higher levels of national certification of the Technical Education and Skills Development Authority. The Council of Australian Governments has supported reform targets that include doubling the number of higher-level (diploma and advanced diploma) qualification completions by 2020 . This is an exerting pressure to increase the number of people with higher educational qualifications.

However, recent trends point to the growing problem of skills mismatch with labor markets. The 2011 Manpower Global Talent Mismatch Survey points out that $41 \%$ of employers surveyed in Asia (compared with $28 \%$ in 2006) reported difficulty in filling positions due to the lack of suitable talent in their markets, compared with a global average of $31 \%$. With a growing incidence of graduate unemployment in Asia's advanced and emerging economies, focus needs to shift to "right skilling" of the workforce.

\section{Aligning Skills Training Policies with Economic and Industrial Policies}

As Asian economies move away from low-cost labor advantages in manufacturing toward knowledge- and technology-intensive industries, the quality of the human resource base is crucial for competitive strength. An appropriate skills strategy is a key component of a successful economic and industrial policy. However, a number of countries, despite prioritizing skills development for economic growth, are yet to ensure adequate harmonization of skills and training policies with economic and industrial policies. The experience from countries like the Republic of Korea; Singapore; Hong Kong, China; and the People's Republic of China demonstrates a strong case for successfully integrating education and policies for skills development into nations' overriding frameworks for economic development. Countries need forward-looking skills policies so that appropriate occupational skills are available to fast-growing and emerging sectors of the economy as shown in Box 20.1.

Box 20.1 Leveraging Skills Training for Competitiveness

\begin{tabular}{ll}
\hline $\begin{array}{l}\text { Common components of growth led by skills } \\
\text { development }\end{array}$ & $\begin{array}{l}\text { Examples of a skills training system that } \\
\text { supports economic strength }\end{array}$ \\
\hline $\begin{array}{l}\text { Government and employers in strategic } \\
\text { economic sectors are committed to }\end{array}$ & $\begin{array}{c}\text { Institutions, processes, and resources are } \\
\text { effective at three levels: } \\
\text { skills development at all levels }\end{array}$ \\
$\quad \begin{array}{l}\text { including high-level technology skills } \\
\end{array}$
\end{tabular}


Box 20.1 (continued)

Skills strategies are supportive of the transition to higher-value-added products and services and priority sectors (e.g., plans for skills development in 20 high-growth sectors in India)

The qualification framework supports development of competency-based skills and standards required by industry

Labor market information and skills forecasting is available and used for skills and training

A sustainable system of funding for higher-level skills development is available with flexible approaches to skills training delivery
Immediate: matching skills to jobs and effectively connecting supply of skilled people to available jobs

Medium term: repairing talent mismatches in the economy through effectively shaping supply to meet demand-side forces

Long term: preparing a pipeline of skilled, semiskilled, and highly skilled workers aligned to the needs of priority sectors of economic and industrial importance, harmonized with investment, financing, and other policy provisions

Source: Chenoy et al. (2011)

\section{Ensuring Industry-Led Systems for Skills Training with a Conducive Regulatory Framework}

There is widespread acknowledgment that the private sector is a critical partner for increasing cost efficiency, quality, and relevance in skills training. Although there is concern about the profit-driven nature of private provision, it is recognized that the private sector can also serve the poor and disadvantaged through voucher schemes and contracted training. Academy-industry partnerships, internships, and placement programs are mechanisms by which the matching of skills with jobs can be strengthened.

However, ensuring congruency of skills with the needs of employers through institution-industry partnerships is easier said than done effectively. On the one hand, a conducive regulatory environment is needed for private sector players to occupy a legitimate space for financing and providing skills training. On the other hand, several supportive measures are required to build a culture of partnershipfor example, training institutions could be required to ensure employer representation on the governing boards and to establish employer advisory committees for each program so that updating and renewal of the curriculum reflect employer expectations. The private sector can also provide ancillary services such as supplies, publishing, and facilities management. Alternative funding mechanisms are needed to ensure that poorly performing public systems are not the only options available to the most disadvantaged. 
Public funding to training institutions could be linked to accountability for performance, such as percentage of graduates employed and employer and employee satisfaction rates from training.

Industry support is required in the design and delivery of a responsive and diversified skills training program that focuses on applied learning. Industry participation is particularly crucial in the context of bodies such as sector skills councils to determine competencies and occupational standards needed in the workforce and to ensure that assessment and certification are acceptable to employers.

Box 20.2 Public-Private Partnerships in Skills Training: Example of India

The unique public-private partnership for skills development in India

Possible contributions from private sector

\begin{tabular}{|c|c|}
\hline $\begin{array}{l}\text { National Skill Development Corporation } \\
\text { (51\% private and } 49 \% \text { government stake; } \\
\text { endowed with a corpus) }\end{array}$ & $\begin{array}{l}\text { Supporting sector skills councils for } \\
\text { assuring talent needed in industry }\end{array}$ \\
\hline $\begin{array}{l}\text { Objectives: } \\
\text { Nurture development with long-term } \\
\text { capital }\end{array}$ & $\begin{array}{l}\text { Setting up standards and quality assurance } \\
\text { to ensure use of global best practices }\end{array}$ \\
\hline $\begin{array}{l}\text { Improve returns by providing viability gap } \\
\text { funding }\end{array}$ & $\begin{array}{l}\text { Modernizing labor market information for } \\
\text { accurate and real-time inputs }\end{array}$ \\
\hline Viable skills ecosystem: & Supporting industry-relevant training \\
\hline $\begin{array}{l}\text { Support systems required for skills } \\
\text { development }\end{array}$ & $\begin{array}{l}\text { Demanding and absorbing "ready-to-work" } \\
\text { and "certified" employees }\end{array}$ \\
\hline Sector skills councils & Supporting internships and placements \\
\hline Quality assurance mechanisms & $\begin{array}{l}\text { Supporting employee cadres to act as } \\
\text { trainers and assessors of competencies }\end{array}$ \\
\hline Information systems & Promoting and rewarding lifelong learning \\
\hline Train-the-trainer programs & \\
\hline Skills standards and competency mapping & \\
\hline
\end{tabular}

Source: Chenoy (2011)

\section{Supporting Qualification Frameworks and Quality Assurance}

Qualification frameworks can strengthen links between education, training, and the labor market. They are means by which industry, government, and training institutions agree on standards for qualifications and learning outcomes. Qualification frameworks can also help to move the workforce toward meeting the economic goals of countries. 
However, it is important to underscore their limitations, as they cannot by themselves make TVET more successful. While the introduction of a qualification framework usually has high levels of commitment from governments, it is more difficult to ensure continued arrangements for quality assurance, certification and accreditation systems, well-conceived learning pathways across different levels of education and training, and regular updating of standards and qualifications. By far the most crucial aspect of a qualification framework's effectiveness is to ensure adequate support from industry and employers. Countries need to consider establishing an appropriate "qualification corridor" that allows workers to move up the skills ladder over time. Industry and employers need to support government initiatives for qualification frameworks by giving preferential treatment to certified persons and favoring the hiring of only skilled people to promote the "skills ecosystem."

\section{Strengthening the Skills and Workforce Development System}

\section{Increasing the Prestige of Skills Training and Rebranding TVET}

Many education systems fragment and split vocational training from academic degrees with no bridge between the two. This often results in TVET being perceived as less prestigious than academic streams. Pathways from TVET to bachelor's and master's degrees are crucial so that students have options for moving from one stream to the other. A more integrated secondary, postsecondary, TVET, and higher education system enables acquisition of qualifications and certification in a flexible and nonhierarchical learning pathway. For higher-order and knowledge-intensive skills, interface with higher education is essential.

The qualifications obtained through TVET could merit reconsideration. TVET is associated with diplomas and certificates, whereas academic streams grant degrees with higher signaling value. In Canada, for example, the 150 colleges, institutes, polytechnics, and universities with a college mandate initially offered 2-3-year technician/technologist diploma programs. In response to demand in recent times, colleges now offer 4-year applied bachelor's degree programs and 1-year postgraduate certificates that target students seeking more practical skills to improve job prospects. Courses offering in Australia start from certificate level going all the way up to doctoral degree. Sri Lanka's qualification system recognizes competencies at different levels, starting from entry level to advanced level. Vocational/technological competencies at level 7 are equivalent to a bachelor's degree. A policy framework that blends skills training with higher education opportunities would help enhance the prestige of TVET and prevent it from being a dead-end learning pathway. 


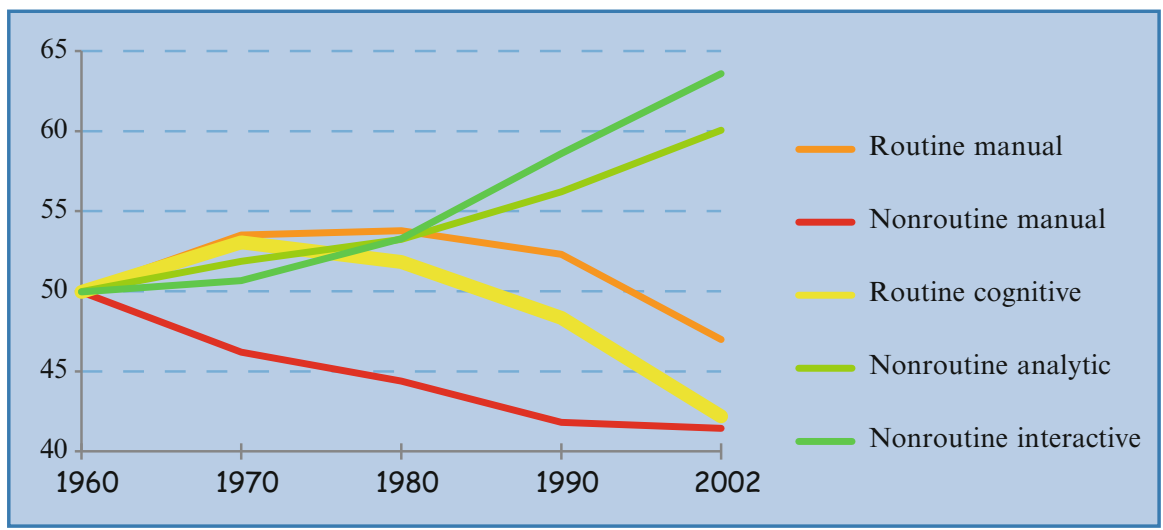

Fig. 20.1 Demand for skills (United States) (Source: Levy and Murnane 2005).

\section{Strengthening Foundational Skills and Direct Measurement of Skills}

As countries move up the value-added chain of production, employment shifts away from jobs involving routine cognitive and manual tasks toward jobs requiring tasks such as critical thinking and complex communication. However, measurement of skills largely focuses on proxies such as years of education or qualifications. More years of education do not necessarily mean higher skills. Qualification-based measures also ignore the fact that skills can be acquired informally and outside the education and training system through work experience. A recently developed instrument by the Organisation for Economic Co-operation and Development, the Programme for International Assessment of Adult Competencies, aims to provide internationally comparable direct assessment of foundational skills of the adult population (ages 16-65) in literacy, numeracy, and problem solving.

There is a growing demand for cognitive skills involving understanding, interpretation, analysis, and communication. Figure 20.1 shows a steep decline in the demand for routine cognitive skills and a sharp increase in the demand for nonroutine interactive skills. While skills training systems need a base of strong foundational skills, they also must adapt rapidly to changing market requirements. This has implications for the design of curriculum and its delivery, the type of courses on offer, and their regular renewal. While routine skills are easiest to teach and test, they are also the ones that are easiest to digitize, automate, and outsource.

\section{Mainstreaming Soft Skills into TVET for Improved Productivity}

The combination of foundational skills, soft skills, and technical skills contributes to successful performance in the workplace. Employers are increasingly stressing 
the importance of soft skills to enhance effectiveness of technical skills. Attributes such as critical thinking, communication, collaboration, creativity, and problem solving enhance application of technical skills. Countries such as Canada are looking into mainstreaming soft skills into technical training programs. Soft skills or employability skills are sometimes considered even more important than technical skills for performance in the workplace.

The focus of skills training is often restricted to increasing enrollments without adequate attention to outcomes from training. Output per worker in developed economies and the European Union was $\$ 72,900$ in 2011 versus an average of $\$ 13,600$ in developing regions (International Labour Organization 2012). Despite increased productivity levels in Asia over the last decade, more attention to output per worker and higher productivity returns from skills training are needed. In addition to expanding access to opportunities for skills training to a large proportion of the population, outcomes from training need to be commensurate with the investments made. Skills utilization is just as valuable to productivity as skills acquisition.

Box 20.3 Examples of Employment Services

\begin{tabular}{|c|c|}
\hline Australian employment services & Jobstreet.com, Philippines \\
\hline $\begin{array}{l}\text { Work placement with post-placement support } \\
\text { and/or workplace mentors }\end{array}$ & $\begin{array}{l}\text { Mediator/bridge between employee and } \\
\text { employer }\end{array}$ \\
\hline $\begin{array}{l}\text { Intensive prevocational training targeted at } \\
\text { basic technical and employability skills }\end{array}$ & $\begin{array}{l}\text { Career Congress series bringing together } \\
150 \text { university representatives with } 100 \\
\text { employers, government, and media }\end{array}$ \\
\hline $\begin{array}{l}\text { Workforce diversity and inclusion strategies } \\
\text { for a supportive environment for the } \\
\text { disadvantages }\end{array}$ & Sharing of best practices \\
\hline $\begin{array}{l}\text { Reverse marketing or "supply push" models } \\
\text { to negotiate vacancies to suit specific job } \\
\text { seekers }\end{array}$ & National Internship Movement \\
\hline Job redesign for people with disabilities & Support to job seekers in critical thinking, \\
\hline $\begin{array}{l}\text { Labour Market Information Portal website } \\
\text { with a wide range of data for skills } \\
\text { forecasting }\end{array}$ & $\begin{array}{l}\text { communication skills, and other soft } \\
\text { skills }\end{array}$ \\
\hline
\end{tabular}

Source: Sinclair and Colet (2011)

\section{Integrating Employment Services into Skills Training}

The design and delivery of skills training have been undergoing rapid change. Traditional institution-based training delivery is giving way to multimode delivery mechanisms. Employment services such as career guidance and placement have become crucial to ease obstacles and constraints to workforce entry. 
Advocacy and support systems for vulnerable groups to participate in labor markets is a valuable ancillary service demonstrated in countries such as Australia and Canada. Apprenticeships and internships are assuming even more prominent roles in strengthening the link between training institutions and employers. Apprenticeship schemes need to be redesigned and modernized so that they are not discredited as a source of cheap labor to employers. On-the-job training is also crucial for improved skills match. There is need to consider modular approaches to skills training and skills updating given the rapid pace of change and transformation in the market place. Lifelong learning and training are crucial for continued workforce participation.

\section{Box 20.4 ADB Support for Strengthening Policies and Practices in Skills Development: An Emerging Framework}

\begin{tabular}{|c|c|c|}
\hline Issues for consideration & Possible policy levers & Possible benefits \\
\hline $\begin{array}{l}\text { Addressing the pressing } \\
\text { challenges of jobs and } \\
\text { skills for development } \\
\text { in Asia }\end{array}$ & $\begin{array}{l}\text { Skills policies linked with } \\
\text { labor market and social } \\
\text { protection policies } \\
\text { Affirmative action to } \\
\text { overcome obstacles to } \\
\text { workforce participation }\end{array}$ & $\begin{array}{l}\text { Increased training opportunities } \\
\text { and improved employment } \\
\text { prospects } \\
\text { Reduced vulnerability and } \\
\text { informality of employment }\end{array}$ \\
\hline $\begin{array}{l}\text { Addressing the paradox of } \\
\text { skills mismatch with } \\
\text { employer needs }\end{array}$ & $\begin{array}{l}\text { Training courses based on } \\
\text { an assessment of "right } \\
\text { skills" required for the } \\
\text { workforce, with a mix of } \\
\text { high, medium, and basic } \\
\text { skills levels. Incentives } \\
\text { for skills development } \\
\text { for high-technology } \\
\text { industry employers }\end{array}$ & $\begin{array}{l}\text { Reduced skills mismatches to } \\
\text { jobs and reduced graduate } \\
\text { unemployment } \\
\text { A highly skilled workforce } \\
\text { supports technology } \\
\text { absorption and moving up } \\
\text { the value chain }\end{array}$ \\
\hline $\begin{array}{l}\text { Leveraging skills training } \\
\text { to improve } \\
\text { competitiveness }\end{array}$ & $\begin{array}{l}\text { Matching skills } \\
\text { development priorities } \\
\text { with economic and } \\
\text { industrial priorities (e.g., } \\
\text { skills, training for pillar } \\
\text { industries in the PRC, } \\
\text { skills development in } \\
\text { the economic master } \\
\text { plan of Indonesia, skills } \\
\text { development for } 20 \\
\text { high-growth industries } \\
\text { in India) }\end{array}$ & $\begin{array}{l}\text { Well-conceived and systematic } \\
\text { skills training frameworks } \\
\text { can support the overall } \\
\text { economic growth } \\
\text { aspirations and global } \\
\text { competitiveness of nations }\end{array}$ \\
\hline $\begin{array}{l}\text { Ensuring industry-led } \\
\text { systems for skills } \\
\text { training }\end{array}$ & $\begin{array}{l}\text { Conducive regulatory } \\
\text { framework for the } \\
\text { private sector. Employer } \\
\text { representation on } \\
\text { governing boards of } \\
\text { training institutions } \\
\text { and employer program }\end{array}$ & $\begin{array}{l}\text { Availability of "work-ready" } \\
\text { human resources and } \\
\text { "certified" employees } \\
\text { A responsive and diversified } \\
\text { skills training system } \\
\text { aligned to industry needs }\end{array}$ \\
\hline
\end{tabular}


Box 20.4 (continued)

advisory committees.

Industry representation

in sector skills councils and in accreditation of skills

Ensuring recognition of skills training and certification but setting realistic expectations from national qualifications frameworks

Increasing the prestige of skills training and rebranding TVET

Developing national qualification frameworks. Industryled occupational standards and their use in training.

Establishment of a "qualification corridor"

Policy framework blending skills training with higher education. Introduction of associate degrees for TVET and applied bachelor's degree programs

Strengthening foundational skills

Mainstreaming soft skills into technical skills training systems

\footnotetext{
Complementing skills training with employment services
} measurement of skills such as the Program for International

Assessment of Adult

Competencies in Asia. Strengthening nonroutine cognitive skills

Incorporation of soft skills development, particularly critical thinking, communication, and collaboration, into training programs

Linking employment services such as career guidance, placement services, internships, and apprenticeship programs with training programs
Using tools for direct and focused on applied learning

Certification, accreditation, and recognition of qualifications and training improve market orientation and confidence in learning outcomes

Horizontal and vertical mobility in learning without dead ends

Increased opportunities to upgrade skills and improve education qualifications

Better assessment of actual skills

Improve foundational skills that help advance skills development.

Application of technical skills at the workplace is improved with good soft skills, and productivity is increased

Training leads to jobs; workforce participation is improved. There is better utilization of skills 
Open Access This chapter is distributed under the terms of the Creative Commons Attribution Non-commercial License which permits any non-commercial use, distribution, and reproduction in any medium, provided the original author(s) and source are credited.

\section{References}

ADB. (2011). Asia 2050 - Realizing the Asian century. Singapore: ADB.

Chenoy, D. (2011, December 12-13). Pathways and modalities for private sector partnerships to meet large scale demand for highly skilled workforce in line with national goals and objectives. International Consultative Forum on Skills for Inclusive and Sustainable Growth in Developing Asia-Pacific. Manila: ADB.

Chenoy, D., Powell, M., \& Sabharwal, M. (2011, December 12-13). Presentation at International Consultative Forum on Skills for Inclusive and Sustainable Growth in Developing Asia-Pacific. Manila: Asian Development Bank.

International Labour Organization. (2012). Global employment trends 2012: preventing a deeper jobs crisis. Geneva: ILO.

Levy, F., \& Murnane, R. (2005). How the demand for skills has changed economy-wide measures of routine and non-routine task input (USA). In R. Desjardins (Ed.), Measuring the skills of the adult population. Presentation at International Consultative Forum on Skills for Inclusive and Sustainable Growth in Developing Asia-Pacific. Manila: ADB.

Sinclair, S., \& Colet, G. (2011, December 12-13). International Consultative Forum on Skills for Inclusive and Sustainable Growth in Developing Asia-Pacific. Manila: ADB. 